\title{
Total Quality Management (TQM) Practices Applied in Education Institutions: A Systematic Review of Literature
}

\author{
Edward Kigozi, James Ko Yuen On \\ University of Hong Kong
}

\begin{abstract}
The purpose of this paper is to present a systematic literature review to identify major total quality management practices used in education institution. The aim was to provide education institutions with reliable evidence for informing their selection of total quality management practices for quality performance improvement. This study used a systematic review of the literature contained in the three databases ERIC, Science Direct and emerald insight. An analysis of the literature identified that top management commitment; continuous improvement and customer focus are the major total quality management practices applied in education institutions. This study was limited by three databases and search engines used and by the restricted number of keywords used in searching these sources. This systematic review of literature shows a gap in the existing research in that most Total quality management researchers put more consideration to higher education and secondary education and less to primary education concerning total quality management practices. This study used a systematic literature review to identify TQM practices used in education institutions and identified that there is still gap in research on TQM practices in primary education.
\end{abstract}

\section{Introduction}

It has now become a common knowledge and understanding that both the developing and developed countries recognize quality of education as the main tool for enhancing human capital development that is needed for their economic growth and prosperity. As such, pressure has been exerted on top management in educational institutions to improve the quality of education in order to satisfy all the stakeholders concerned and at the same time remain competitive and relevant amidst reduced budget allocations with increased student enrollments [21], [22], [25]. In order to improve the quality of education and satisfying the diverse stakeholders in the presence of the aforementioned challenges, educational institutions have adopted TQM practices that are similar to those applied in industries and business organizations [18], [2], [26], [11], [13].
According to empirical studies conducted by Prajogo \& Sohal [18], Lam et al. [11], Sahney et.al. [21], Kanji, Malek, \& Tambi [10] have indicated that implementing TQM practices improves both service quality and market quality in various organizations. In addition, some systematic literature reviews have been conducted for instance Owlia \& Aspinwall [16] on comparison of how quality models in higher education institutions have been adapted from business. Manatos et al. [13] conducted a systematic review of literature aimed at examining how quality management models have been integrated in higher education institutions' management systems conducted another systematic review of literature. The reviews conducted by the previous scholars focused mainly quality management models and specifically in higher education institutions. The primary aim of this systematic review of literature was to analyze published research on TQM practices in Education institutions such as primary, secondary and higher education institutions to identify the total quality management practices applied in them. To ensure a comprehensive coverage in this systematic literature review three databases are used: ERIC, Emerald, and Science Direct. This paper starts with a literature review, followed by the methodology adopted in this systematic review before a final, results, discussion and recommendations. The next section presents some studies that have been conducted on TQM practices in educational institutions.

\section{Literature Review}

This section presents selected studies on TQM practices implemented in education institutions

\subsection{Selected studies on TQM practices in education institutions}

TQM practices are also referred to as critical success factors whose aim is to improve the performance of firms, or organizations' success of TQM process and programs [10], [6], [30]. Various studies have been conducted to identify the TQM practices in various organizations such as health, business, industrial and education institutions [25], [24]. In order to provide adequate understanding of 
TQM practices in educational institutions, a summary of previous studies conducted by various scholars is presented. A review conducted by Owlia \& Aspinwall [16] using 18 articles identified top management commitment, strategic planning, organization quality, employee involvement, team working, training for quality, design management, and process management, superior quality management and analysis as the main TQM practices applied in higher educational institutions in UK and US.

In another review, Manatos et al. [13] analyzed the literature on total quality management practices in higher education, with Elsevier's Scopus databases, the articles included in their studies were based on methodological approaches using 58 articles. In their review, the following total quality management practices were identified: customer focus, leadership, continuous improvement, factual approach and supplier relationships and all the total quality management were based on total quality management in higher education institutions. Ngware et al. [29] carried out a study in secondary schools in Kenya, whose aim was to investigate the extent to which secondary schools practiced the aspects of total quality management. Basing on their study, leadership, strategic planning and human resource development were identified as the major total quality management practices in applied in secondary schools in Kenya. They also concluded that most head teachers apply leadership to empower their teachers, majority of the schools were not committed to strategic quality planning though they do promote human resource development initiatives. In Turkey, Töremen et al. [26] conducted a study in primary schools, whose aim was to determine the extent of total quality management practices applied in primary schools basing on teachers perceptions applying a survey based descriptive scanning model on a sample of 420 teachers. From the study the following total quality management practices were identified; clarity of school principals, school management, school involvement, quality of school life, change management, adoption of total quality management philosophy.

Accordingly, Nawelwa et al. [31] studied TQM practices in secondary schools in Zambia and identified teamwork, continuous improvement, training, and management commitment as the major TQM practices used in secondary schools in Zambia. The empirical study by conducted in Higher education institutions in Jordan found out that leadership and student, stakeholder and market foci as the major TQM practices.

In a quantitative study conducted by Alsuhaimi (2012) in Saudi Arabia aimed at exploring the implementation of TQM and its practices, the results of the study identified customer focus, leadership, design quality, strategic quality planning, people participation, fact-based management and continuous improvement as the major TQM practices in higher education. On the other hand, Alzhrani et al. [15] carried out a study in Saudi Arabian higher education institutions. Basing on their study the suggested, a model of TQM practices applied in higher education institutions as consisting of the following practices: education quality programs, physical evidence quality, faculty and staff quality, curriculum quality, student quality, administrative and regulation quality.

From the literature review conducted it is observed that two studies were systematic reviews i.e. the study by Manatos et al. [13] and Owila, and Aspinwal [16]. The other studies were systematic reviews and were conducted in higher education institutions while the studies by Ngware et al. [29], Töremen et al. [26], Nawelwa et al. [31], Alsuhaimi (2012) and Alzhrani et al. [15] were empirical studies. The literature review also revealed that top management commitment, leadership, continuous improvement, employee involvement, customer focus and strategic planning are the most dominant practices applied in the education institutions while implementation TQM. The next section presents the methodology and design applied while conducting the study.

\section{Research Methodology and Design}

A systematic review of published papers on TQM practices applied in educational institutions has been employed as the methodology in this paper. According to Tranfield et al. [27] and Page, a Systematic review is a crucial tool used for enhancing debate and dissemination of academic findings from various scholars. In the same vein, Manatos et al. [13] points out that a systematic review is a method used to identify, assesses and analyses contributions already published to study guided by a particular research question. This subsection presents the steps for conducting the review namely, planning for the review, conducting the review, reporting and dissemination of the findings. 
Table 1. Summarizes the result of the literature search

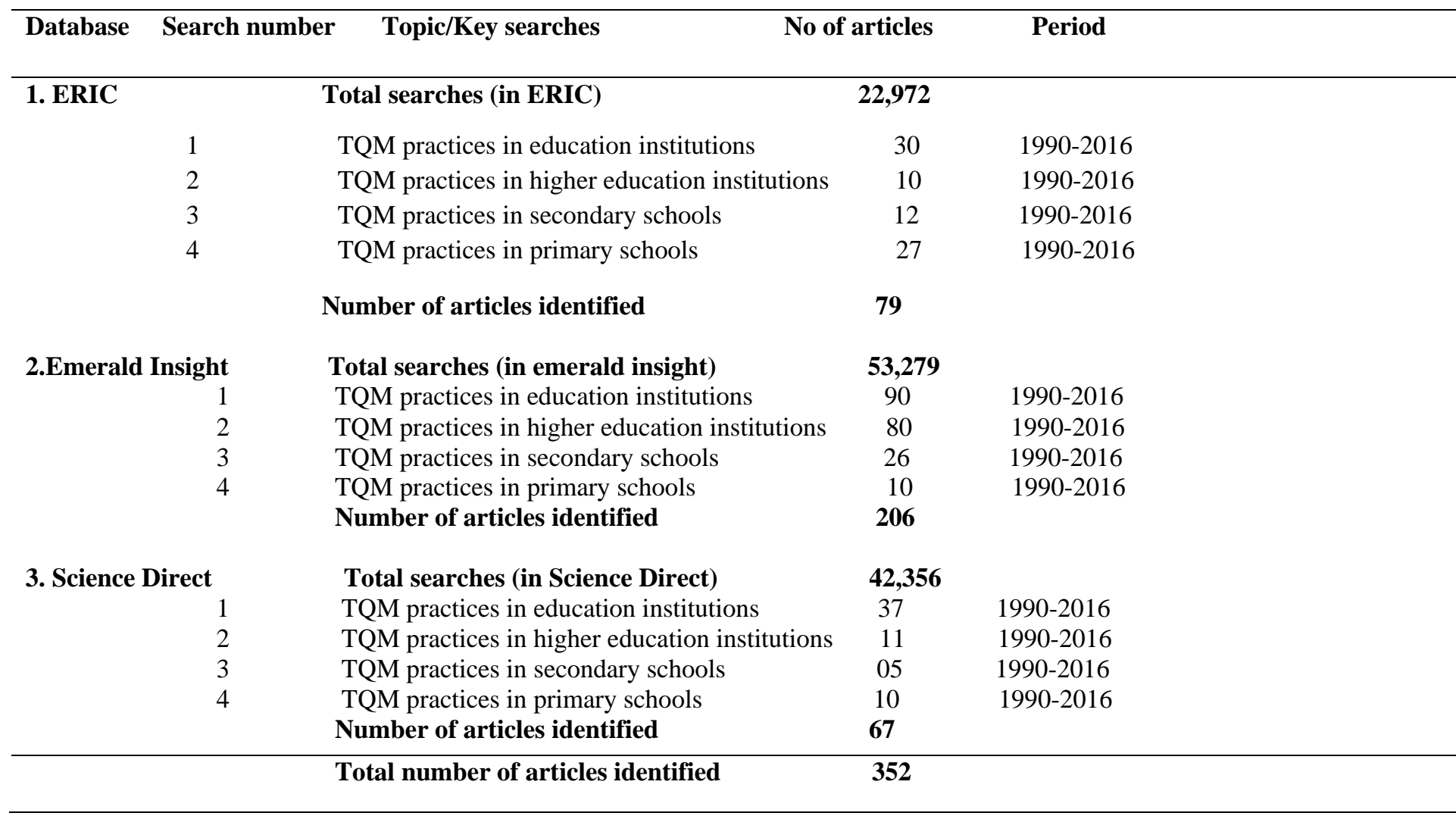

\section{Source: literature review}

\subsection{Planning the review}

The paper presented a systematic review of literature on TQM practices applied in education institutions. Various scholars have conducted their systematic reviews using the strategies and methodologies applied by [27]. For instance scholars as Tari [24] in his review of theoretical and empirical evidence of trends towards the integration of quality management in universities reviewed their articles according to journals using three databases namely, the search strategy for identifying their studies involved the use of databases mainly ABI Inform, Emerald and Science Direct databases; Manatos et al. [35] in their systematic review of literature on the integration of quality management systems in higher education used Elsevier's Scopus, Google scholar and web of science as their databases to identify their studies for the review; Tari [24] in his systematic review of literature on trends in quality management research in higher education institutions using databases namely, Science Direct, ABI/Inform, and Emerald. Interestingly, though all the previous scholars have conducted systematic reviews with different foci and databases they have employed the strategies that have been used by Transfield et al. [30] which involve: i) planning the review, ii) conducting the review, and iii) reporting and dissemination of the findings. Like, the previous systematic reviews of literature conducted, this review also adapted the procedures suggested by Transfield et.al. [30] to identify the TQM practices applied in education institutions.

The choice for adapting the aforementioned methodology and strategies is underpinned by the fact that it is transparent, reliable, and free of bias as supported by [17]. However, Page contends that although systematic reviews are transparent and reliable in their findings, they are liable to some shortcomings such as conflicting results, ambiguity, poorly defined and constantly changing terms. While conducting this systematic review of literature three databases were used namely, ERIC, Emerald, and Science Direct the choice of the databases was basing on the reason that they contain that first, ERIC contains the largest number of abstracts covering education area and it permits complex searches [12]. Secondly, Emerald Insight and Science Direct contain some of the largest source of abstracts, citation of peer-reviewed literature in most important journals on TQM implementation in education and other interdisciplinary publications that are related to quality and TQM implementation in education institutions [14]. To obtain a broad view of the total quality management practices applied in education institutions the review was restricted to published 
peer-reviewed works in English language journals from ERIC, Emerald Insight, and Science Direct databases. The search terms used in the review were: i) Total quality management practices in educational institutions, ii) Total quality management practices in Higher education institutions, iii) Total quality management practices in secondary schools, iv) Total quality management practices in primary schools. These search topics here searched in all the three databases namely ERIC, Emerald Insight and Science direct. The summary of the number searches per database used in the systematic review is shown in the following Table 1.

From the Table 1 above it be observed that Emerald Insight has the largest number searches, 53,279 with 206 articles identified, followed by ERIC with 22,972 searches and 79 articles identified and then science direct having 42,356 searches with 67 articles identified thus giving a total of 352 articles identified.

\subsection{Conducting the review}

During this of a series of steps were done using the following criteria:

- The study should be composed of primarily total quality management in educational institutions.

- The study should be an empirical study or a systematic review.

- The study should be peer-reviewed and published in English journals.

After obtaining the electronic copies of the studies, the studies that passed through the initial screening, were then subjected to the second screening to establish if they really met the inclusion criteria. Before the study could be included in the review their abstracts and title were evaluated and assessed for inclusion using the full text, as recommended by Valentine et al. [27].

The searches yielded a total of 358 studies; Science direct (63 studies), Emerald insight (216 studies) and ERIC (79 studies), these were reduced to 228 studies because of the following reasons;

- Excluded on titles and abstracts

- Conference papers

- Lack of critical review on TQM practices in education institutions

- Not being focused on TQM practices in education institutions

These were scrutinized for the second time to ensure that their contents are relevant to the primary aim of the review and this resulted into 130 studies.

The reasons for this reduction were:
- Lack of critical review on TQM practices in educational institutions.

- Not being focused on TQM practices in educational institutions.

First, the abstracts of the articles were read and if these are not clear on any aspect, the full version of the article of the paper was reviewed. The reason for this exclusion was:

- Were theoretical papers

- Were Duplicates

- No critical review on TQM practices in education institutions

- Not focused on TQM practices in education institutions

The studies were further scrutinized to ensure that their contents are relevant to the primary aim of the review and this resulted into 130 studies. The reasons for this reduction were; i) lack of critical review on TQM practices in education institutions, ii) not being focused on TQM practices in educational institutions. First, the abstracts of the articles were read and if these are not clear on any aspect, the full version of the article of the paper was reviewed. The reason for this exclusion was; i. Were theoretical papers, ii) Were Duplicates, iii) No critical review on TQM practices in educational institutions, and iv) Not focused on TQM practices in educational institutions. This resulted in the exclusion of 120 studies because they did not fulfill the criteria for inclusion leaving only 10 papers for the detailed analysis against the prescribed assessment criteria. The summary of the inclusion and exclusion criteria is as shown in the following Figure 1.

\subsection{Reporting and Dissemination}

While reporting the assessment of each article, the title, author(s), the journal and the database in which articles were identified and their numbers were presented in a Table. The summary of the number of articles per database are shown in the following Table 2.

From Table 2 above it can be observed that emerald insight database had the highest number of articles (5), followed by ERIC (05) and finally no study on TQM practices was identified in science direct database. Summary of the studies and their findings is presented in the following Table 3. 
Figure 1. summary of the inclusion and exclusion criteria of the studies

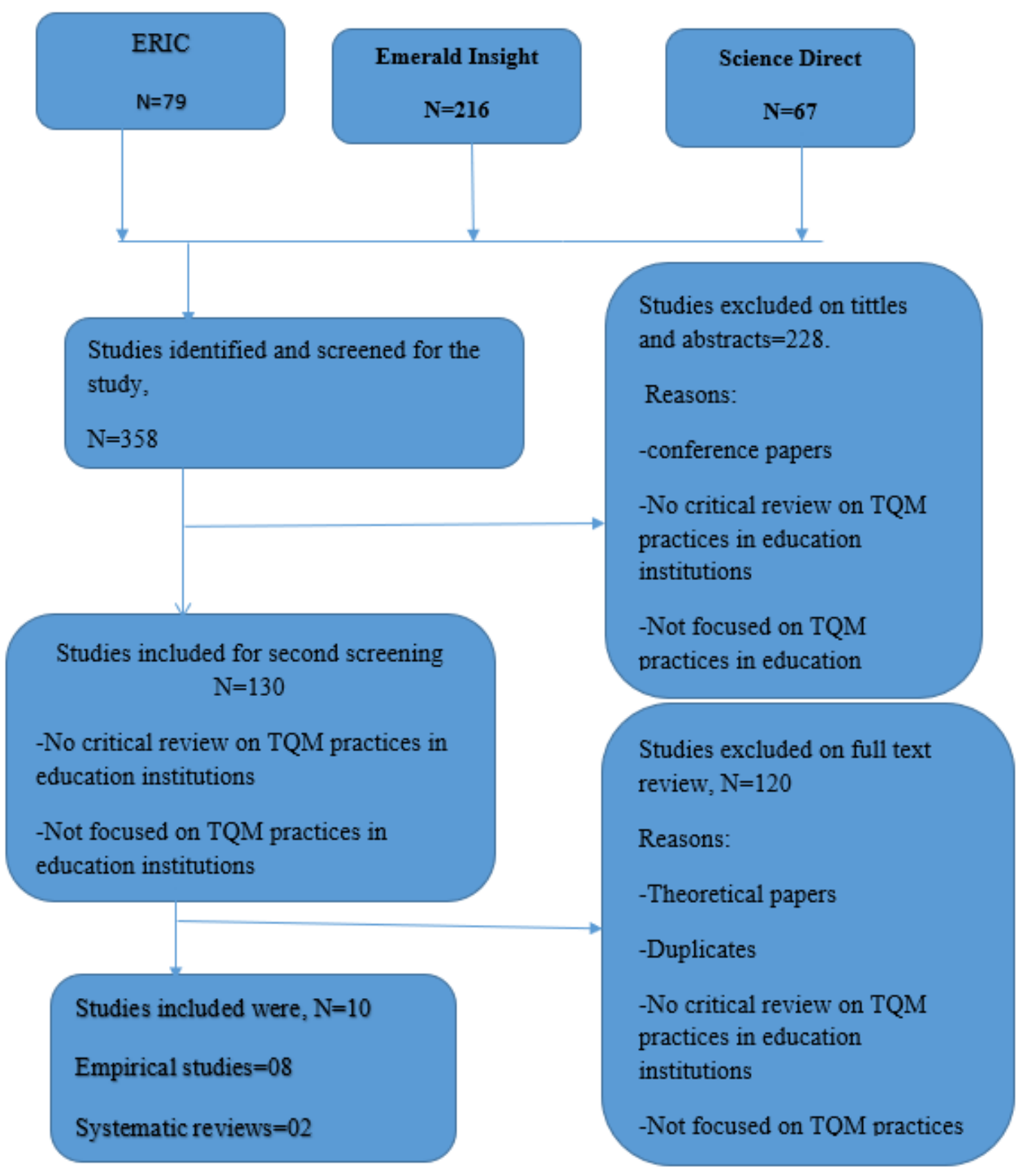

Table 2. Summarizes the results of the final search for the review

\begin{tabular}{lcc}
\hline Database & Studies identified & Number of studies included \\
ERIC & 79 & 05 \\
Emerald Insight & 216 & 05 \\
Science direct & 67 & 00 \\
\end{tabular}


Table 3. Summaries the studies and their findings

\begin{tabular}{|c|c|c|c|}
\hline \multirow[t]{5}{*}{ ERIC } & $\begin{array}{l}\text { Author (s) } \\
\text { 1. Olasunkanmi \& } \\
\text { Abbas (2016) }\end{array}$ & $\begin{array}{l}\text { Tittle } \\
\text { Analysis of Total quality } \\
\text { management practices in } \\
\text { Lagos state tertiary } \\
\text { education institutions }\end{array}$ & $\begin{array}{l}\text { Findings } \\
\text { - } \quad \text { Resources and infrastructure } \\
\text { management } \\
\text { - } \quad \text { Leadership of management }\end{array}$ \\
\hline & 2.Töremen (2009) & $\begin{array}{l}\text { Total quality } \\
\text { management practices in } \\
\text { Turkish } \quad \text { primary } \\
\text { schools. }\end{array}$ & $\begin{array}{ll}\text { - } & \text { Leadership } \\
\text { - } & \text { Education } \\
\text { - } & \text { Continual improvement } \\
\text { - } & \text { Stake-holders involvement } \\
\text { - } & \text { Teamwork }\end{array}$ \\
\hline & 3.Ismail (2014) & $\begin{array}{l}\text { Total quality } \\
\text { management }(\text { TQM) } \\
\text { practices and school } \\
\text { climate amongst high, } \\
\text { average and low- } \\
\text { performance secondary } \\
\text { schools. }\end{array}$ & $\begin{array}{ll}\text { - } & \text { Staff involvement } \\
\text { - } & \text { Top management commitment }\end{array}$ \\
\hline & $\begin{array}{l}\text { 4. Psomas and } \\
\text { Antony (2015) }\end{array}$ & $\begin{array}{l}\text { Total quality } \\
\text { management elements in } \\
\text { higher education } \\
\text { institutions. The Greek } \\
\text { case. }\end{array}$ & $\begin{array}{ll}\text { - } & \text { Students focus } \\
\text { - } & \text { Leadership and } \\
& \text { Top management } \\
\text { - } & \text { Strategic quality planning } \\
\text { - } & \text { Employee involvement }\end{array}$ \\
\hline & $\begin{array}{l}\text { 5.Prueangphitchay } \\
\text { athon, Tesaputa, \& } \\
\text { Somprach (2015) }\end{array}$ & $\begin{array}{l}\text { Application of total } \\
\text { quality management } \\
\text { system in Thai primary } \\
\text { schools }\end{array}$ & $\begin{array}{ll}\text { - } & \text { Strategic planning } \\
\text { - } & \text { Student focus } \\
\text { - } & \text { Stakeholders focus } \\
\text { - } & \text { Knowledge management and } \\
\text { - } & \text { measurement } \\
\text { Process management }\end{array}$ \\
\hline \multirow[t]{2}{*}{$\begin{array}{l}\text { Emerald } \\
\text { Insight }\end{array}$} & $\begin{array}{l}\text { 1.Venkatraman } \\
(2007)\end{array}$ & $\begin{array}{l}\text { A framework for } \\
\text { implementing } \text { TQM in } \\
\text { higher } \\
\text { programs }\end{array}$ & $\begin{array}{ll}\text { - } & \text { Leadership } \\
\text { - } & \text { Quality culture } \\
\text { - } & \text { Continuous improvement } \\
\text { - } & \text { Employee participation } \\
\text { - } & \text { Fast response } \\
\text { - } & \text { Information management } \\
\text { - } & \text { Customer-driven quality } \\
\text { - } & \text { Partnership development }\end{array}$ \\
\hline & $\begin{array}{l}\text { 2. Owlia and } \\
\text { Aspinwall (1996) }\end{array}$ & $\begin{array}{l}\text { TQM in higher } \\
\text { education }- \text { a review }\end{array}$ & $\begin{array}{ll}\text { - } & \text { Top management commitment } \\
\text { - } & \text { Strategic planning } \\
\text { - } & \text { Organization for quality } \\
\text { - } & \text { Employee involvement } \\
\text { - } & \text { Teamwork } \\
\text { - } & \text { Training for quality } \\
\text { - } & \text { Design management }\end{array}$ \\
\hline
\end{tabular}




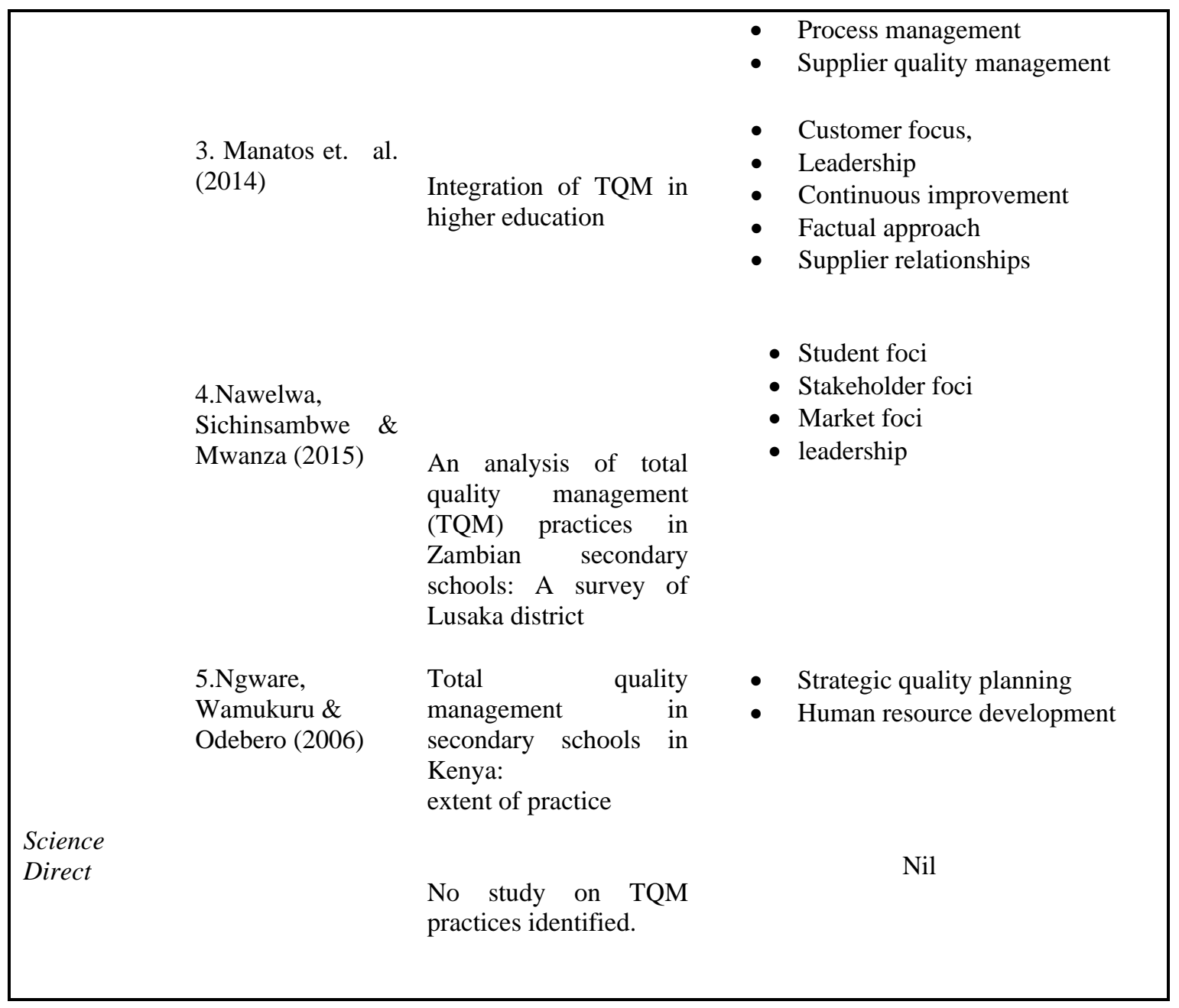

\subsubsection{Relevance of the studies included into the} review. The relevance of the included studies was determined by assessing the number of TQM practices identified in a particular study. The more TQM practices identified the more relevant the study was and the fewer TQM practice identified in the study the less relevant the study was.

The criterion for relevance assessment was as follows: (i) More than 9 TQM practices identified then the study was considered more relevant.

(ii) Between 5 to 8, TQM practices identified, and then the study was considered moderately relevant.

(iii) Between 1 to 4 , the study was considered less relevant.

The summary of the relevance of the studies identified in the review is presented in the following Table 4.

Table 3. summarizes the relevance of the studies included in the review

\begin{tabular}{|c|c|c|c|c|}
\hline Author & Study & $\begin{array}{l}\text { Number of } \\
\text { TQM practices } \\
\text { identified }\end{array}$ & $\begin{array}{l}\text { Fraction } \\
\text { of TQM } \\
\text { practices }\end{array}$ & $\begin{array}{ll}\text { Level } & \text { of } \\
\text { relevance }\end{array}$ \\
\hline $\begin{array}{l}\text { 1.Owila } \quad \& \quad \text { Aspinnwal } \\
\text { (1997) }\end{array}$ & $\begin{array}{l}\text { TQM in the higher } \\
\text { education-A review. }\end{array}$ & 09 & $09 / 38$ & More Relevant \\
\hline 2. Manatos et al. (2014) & $\begin{array}{l}\text { Integration of TQM in } \\
\text { higher education }\end{array}$ & 04 & $04 / 38$ & Less relevant \\
\hline
\end{tabular}




\begin{tabular}{|c|c|c|c|c|}
\hline $\begin{array}{l}\text { 3. Ngware, Wamukuru \& } \\
\text { Odebero (2006) }\end{array}$ & $\begin{array}{l}\text { Quality management } \\
\text { practices in Kenyan } \\
\text { educational } \\
\text { institutions: the case } \\
\text { of the University of } \\
\text { Nairobi. }\end{array}$ & 03 & $03 / 38$ & Less relevant \\
\hline 4.Töremen (2009) & $\begin{array}{l}\text { Total quality } \\
\text { management practices } \\
\text { in Turkish primary } \\
\text { schools. }\end{array}$ & 05 & $05 / 38$ & $\begin{array}{l}\text { Moderately } \\
\text { relevant }\end{array}$ \\
\hline $\begin{array}{l}\text { 5.Nawelwa, Sichinsambwe, } \\
\text { \& Mwanza (2015) }\end{array}$ & $\begin{array}{l}\text { An analysis of total } \\
\text { quality management } \\
\text { (TQM) practices in } \\
\text { Zambian secondary } \\
\text { schools A survey of } \\
\text { Lusaka district }\end{array}$ & 04 & $04 / 38$ & Less relevant \\
\hline 6.Ismail (2014) & $\begin{array}{l}\text { Total quality } \\
\text { management (TQM) } \\
\text { practices and school } \\
\text { climate amongst high, } \\
\text { average and low- } \\
\text { performance } \\
\text { secondary schools. }\end{array}$ & 02 & $02 / 38$ & Less relevant \\
\hline $\begin{array}{l}\text { 7.Prueangphitchayathon, } \\
\text { Tesaputa,\& } \quad \text { Somprach } \\
\text { (2015) }\end{array}$ & $\begin{array}{l}\text { Application of total } \\
\text { quality management } \\
\text { system in Thai } \\
\text { primary schools }\end{array}$ & 04 & $04 / 38$ & Less relevant \\
\hline 8.Venkatraman (2007) & $\begin{array}{l}\text { A framework for } \\
\text { implementing TQM in } \\
\text { higher education } \\
\text { programs }\end{array}$ & 08 & $08 / 38$ & $\begin{array}{l}\text { Moderately } \\
\text { relevant }\end{array}$ \\
\hline $\begin{array}{l}\text { 9.Olasunkanmi, \& Abbas } \\
\text { (2016) }\end{array}$ & $\begin{array}{l}\text { Analysis of Total } \\
\text { quality management } \\
\text { practices in Lagos } \\
\text { state tertiary education } \\
\text { institutions }\end{array}$ & 02 & $02 / 38$ & Less relevant \\
\hline $\begin{array}{l}\text { 10. (Psomas and } \\
\text { Antony2015) }\end{array}$ & $\begin{array}{lr}\text { Total } & \text { quality } \\
\text { management elements } \\
\text { in higher education } \\
\text { institutions. } \\
\text { Greek case. }\end{array}$ & 05 & $05 / 38$ & Less relevant \\
\hline
\end{tabular}

Source: Literature review 
According to the review 38 TQM practices were identified. Furthermore, the study conducted by Owila \& Aspinnwal [16] and Venkatraman [34] had the highest number of TQM practices i.e. 9 and 8 respectively and these were regarded as being more relevant and moderately relevant. On the other hand, studies conducted by Psomas and Antony [20], and Toremen et al. [33] had 5 TQM practices which was regarded as being less relevant. Similarly, Prueangphitchayathon, Tesaputa,\& Somprach [19], Ismail [8], Nawelwa [31], Ngware et al. [29], had 4
TQM practices each as well as those by Ismail [8] which also had 2 TQM practices and were all regarded less relevant as according to the conditions set in section 3.3.1.

\section{Findings and Discussion}

This section presents the total quality management practices that were identified in the various studies that were included in the review and their patterns.

Table 4. showing total quality management practices identified from the review

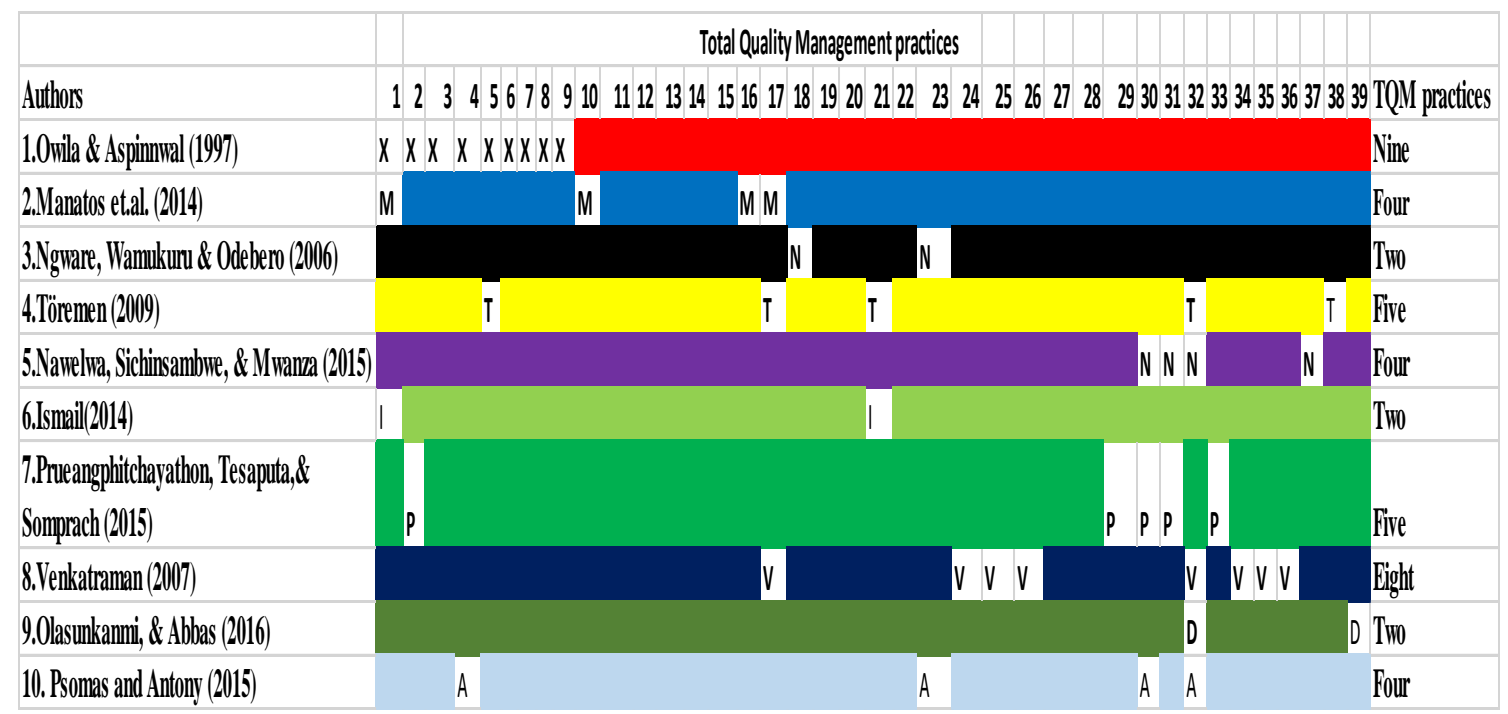

\section{Source: Literature review}

From Table 5 the following TQM practices were identified from the review: 1. Top management commitment, 2. strategic planning, 3. Organization quality, 4. Employee involvement, 5. Team work, 6. Training and education, 7. Design management, 8. Process management, 9. Superior quality management and analysis, 10. Factual approach and supplier relationships, 11. Clarity of school principals, 12. School management, 13. School improvement, 14. Quality of school life, 15. Change management, 16.Customer focus, 17. Continuous improvement, 18.Human resource, 19. Evaluation quality, 20. Stakeholder involvement, 21. Staff involvement, 22. Student focus, 23. Strategic quality planning 24. Employee participation, 25. Customer-driven policy, 26. Partnership development, 27. Training for quality, 28. Design management, 29. Process management, 30. Student focus, 31. Stakeholder focus, 32. Leadership and Top management commitment, 33. Knowledge management and measurement, 34quality culture, 35. Fast response, 36. Information management, 37. Market foci, 38. Education and 39. Resource and infrastructure.

In addition, Table 5 shows that TQM practices identified by Owila \& Aspinnwal [16], takes a pattern
XXX from 1 to 9 and not any other TQM practice was identified in the study. Interestingly, there is an empty coverage from 10 to 39 , which is marked by a red color indicating that they did not put emphasis on the TQM practices in this area. Venkatraman [34] in his study discovered eight TQM practices that are applied in higher education institutions and his study took a pattern VVV. On the other hand, Toremen et al. [33] in his study on TQM in Turkish primary schools identified five TQM practices, which took the pattern TTT. Accordingly, scholars such as Manatos et.al. [13], Psomas and Antony [20] and Nawelwa et al. [31] identified four TQM practices in their studies. Their studies took the patterns MMM, AAA and III respectively. The studies conducted by Ismail [8] and Ngwale et.al [29] each identified two TQM practices. Apart from the study by Owila \& Aspinnwal [16], the pattern of the TQM practices identified by other scholars is sparsely arranged which indicates that there is differential emphasis in the choice of TQM practices applied in education institutions.

The TQM practices identified by the study are categorized into the following groups: 
i)Top management commitment which includes the following practices: leadership, management, superior quality management and analysis, school management, resource and infrastructure, design management, process management, Information management, clarity of school principals, knowledge management and measurement, change management, Strategic quality planning, strategic planning and quality culture. According to Ater and No [1], top management commitment and leadership are an important factor in TQM implementation because they improve quality, performance through influencing other TQM practices. This is also in agreement with Lawler [7] and Brown [3], who point out that successful TQM implementation needs full participation and commitment of top management which is necessary for the creation of a quality culture that involves everyone.

ii) Continuous improvement: the practices under this category are: school improvement, continuous improvement, education and training, evaluation quality, partnership development, factual approach and supplier relationships and training for quality.

The most important TQM practice identified were leadership, employee involvement, strategic planning, customer focus and top management commitment. Successful TQM implementation is need as reduces defects, improves internal quality which leads to satisfaction of the needs and expectations of the customers [23].

iii) Employee involvement: the TQM practices categorised in this group include, teamwork, human resource, stakeholder involvement, and staff involvement and employee participation. This also another important factor in implementing TQM. This is supported by Lawler [32] and Ater [1] who contend that when employees are involved in the daily running of the organization such as participating in decision making, policy formulation they acquire new knowledge, obtain a sense of accomplishment of goals and objectives and inspires them towards attaining its quality goals [2], [32].

iv) Customer focus: this include, student focus, market focus, fast response, and stakeholder focus. The major aim of TQM implementation is to provide services that satisfy the needs and expectations of the customers. Notable theorists such as Deming [5], Juran [9] and Crosby [4] noted that customer focus is an important factor in organizations seeking to improve quality.

\section{Conclusion}

The major aim of this systematic review of literature was to identify the total quality management practices applied in education institutions. It is evident from the review that top management comment and leadership are a key dimension for the total quality management and development of the other QM dimensions and it acts as a pivot on which quality of institutions depends. Therefore, senior managers need to consult with all stakeholders to establish quality policies and objectives that will act as a guide for QM activities to meet other quality dimensions [16], [29]. Therefore, it is important to collect information from all stakeholders and analyze these needs to best inform QM objectives, measurement of teaching and learning activities and to define improvement actions (Mwanza, 2015). According to Owila \& Aspinnwal, [16] this requires that top management and leadership should involve other stakeholders in educational institutions such as students, graduates, employers and that student plays different roles, as customers and as active participants in the processes they experience. It can also be noted from the review that Total quality management practices are highly well researched and employed in higher education institutions and secondary schools compared to primary schools.

\section{Implication}

This systematic review of literature shows a gap in the existing research in that most Total quality management researchers put more consideration to higher education and secondary education and less to primary education concerning total quality management practices

\section{References}

[1] Ater, Jackline Atieno (2013). "Challenges Facing the Implementation of Total Quality Management Practices in Public Secondary Schools In Kenya." Unpublished MBA Project. Nairobi: Kenyatta University.

[2] Demirbag, M., Tatoglu, E., Tekinkus, M., (2006). “An Analysis of the Relationship between TQM Implementation and Organizational Performance: Evidence from Turkish SMEs." Journal of Manufacturing Technology Management, vol. 17, no. 6, pp. 829-847.

[3] Brown, A., (2013). "Quality: Where Have We Come from and What Can We Expect?" The TQM Journal, vol. 25 , no. 6 , pp. 585-596.

[4] Crosby, P. B., (1979). "Quality Is Free: The Art of Making Quality Certain New York.” NY: McGraw.

[5] Deming, W. E., (1986). "Out of Crisis, Centre for Advanced Engineering Study." Massachusetts Institute of Technology, Cambridge, MA. 
[6] Osseo-Asare, E. A., and Longbottom, D., (2002). "The Need for Education and Training in the Use of the EFQM Model for Quality Management in UK Higher Education Institutions." Quality Assurance in Education, vol. 10, no. 1, pp. 26-36.

[7] Feigenbaum, A.V., (1994). "Quality Education and America's Competitiveness." Quality Progress, vol. 27, no. 9, p. 83.

[8] Ismail, Siti Noor (2015). "Total Quality Management (TQM) Practices and School Climate amongst High, Average and Low Performance Secondary Schools." Malaysian Journal of Learning and Instruction, vol. 11, pp. 41-58.

[9] Juran, J. M. (1995). "A History of Managing for Quality: The Evolution, Trends, and Future Directions of Managing for Quality". ASQC Quality press Milwaukee.

[10] GK Kanji, A. Malek, BA Tambi (1999). "TQM in US Higher Education." Best on Quality, IAQ Book Series, vol. 10.

[11] SY Lam, VH Lee, KB Ooi, (2012). "A Structural Equation Model of TQM, Market Orientation and Service Quality: Evidence from a Developing Nation." Managing Service Quality: An International Journal, vol. 22, no. 3, pp. 281-309.

[12] Lefebvre, C., Glanville, J., Beale, S., Boachie, C., Duffy, S., (2008). "Searching for Studies." Cochrane Handbook for Systematic Reviews of Interventions: Cochrane Book Series, pp. 95-150.

[13] Manatos, M. J. P., (2017). "The Integration of Quality Management in Higher Education Institutions: A Systematic Literature Review." Total Quality Management \& Business Excellence, vol. 28, no. 1-2, pp. 159-175.

[14] Meho, Lokman I., and Yvonne Rogers (2008). "Citation Counting, Citation Ranking, and h-Index of Human-Computer Interaction Researchers: A Comparison of Scopus and Web of Science." Journal of the American Society for Information Science and Technology, vol. 59, no. 11, pp. 1711-1726.

[15] Khadijah Mohammed Alzhrani, Bashayer Ali Alotibie, Azrilah Abdulaziz (2016). "Total Quality Management in Saudi Higher Education." International Journal of Computer Applications, vol. 135, no. 4, pp. 6-12.

[16] Owila, Mohammad S., and Elaine M. Aspinwall (1997). "TQM in Higher Education-a Review." International Journal of Quality \& Reliability Management, vol. 14 , no. 5 , pp. 527-543.

[17] Diana Papaioannou, Anthea Sutton, Christopher Carroll, Andrew Booth \& Ruth Wong (2010). "Literature Searching for Social Science Systematic Reviews: Consideration of a Range of Search Techniques." Health Information \& Libraries Journal, vol. 27, no. 2, pp. 114122.

[18] Prajogo, Daniel I., and Amrik S. Sohal (2006). "The Relationship between Organization Strategy, Total Quality
Management (TQM), and Organization Performance the Mediating Role of TQM." European Journal of Operational Research, vol. 168 , no. 1, pp. 35-50.

[19] Setthiya Prueangphitchayathon, Kowat Tesaputa, and Kanokorn Somprach (2015). "Application of Total Quality Management System in Thai Primary Schools." Educational Research and Reviews, vol. 10, no. 11, pp. 1535-1546.

[20] Psomas, Evangelos, and Jiju Antony (2017). "Total Quality Management Elements and Results in Higher Education Institutions: The Greek Case." Quality Assurance in Education, vol. 25, no. 2, pp. 206-223.

[21] S. Sahney, DK. Banwet and S. Karunes (2004) "Identification of Elements of Total Quality Management for the Educational System: A Study of Select Engineering and Management Institutions in India." Vision, vol. 8, no. 1, pp. 11-24.

[22] Salaheldin, Salaheldin Ismail, and Banan A. Mukhalalati. (2009)."The Implementation of TQM in the Qatari Healthcare Sector." Journal of Accounting, Business \& Management, vol. 16, no. 2.

[23] Svensson, M., and Bengt, K., (2006). "TQM-Based Self-Assessment in the Education Sector: Experiences from a Swedish Upper Secondary School Project." Quality Assurance in Education, vol. 14, no. 4, pp. 299-323.

[24] Tarí, Juan José (2011). "Research into Quality Management and Social Responsibility." Journal of Business Ethics, vol. 102, no. 4, pp. 623-638.

[25] Tarí, Juan José, and Gavin Dick. (2016). "Trends in Quality Management Research in Higher Education Institutions." Journal of Service Theory and Practice, vol. 26, no. 3, pp. 273-296.

[26] F. Töremen, M. Karakuş, T. Yasan (2009). "Total Quality Management Practices in Turkish Primary Schools." Quality Assurance in Education, vol. 17, no. 1, pp. 30-44.

[27] D. Tranfield, D. Denyer, P. Smart (2003). "Towards a Methodology for Developing Evidence-Informed Management Knowledge by Means of Systematic Review." British Journal of Management, vol. 14, no. 3, pp. 207-222.

[28] Jeffrey C. Valentine, Amy S. Hirschy, Christine D. Bremer Walter Novillo, Marisa Castellano and Aaron Banister (2011). "Keeping At-Risk Students in School: A Systematic Review of College Retention Programs." Educational Evaluation and Policy Analysis, vol. 33, no. 2, pp. 214-234.

[29] Ngware, M.W., Wamukuru, D.K., Odebero, S.O., (2006) "Total quality management in secondary schools in Kenya: extent of practice", Quality Assurance in Education, Vol. 14 Issue: 4, pp.339-362

[30] AA Wali, SG Deshmukh, AD Gupta, (2003). "Critical Success Factors of TQM: A Select Study of Indian Organizations." Production Planning \& Control, vol. 14, no. 1 , pp. 3-14. 
[31] Nawelwa, J., et al. (2015). “An Analysis of Total Quality Management (TQM) Practices in Zambian Secondary Schools: A Survey of Lusaka District." The TQM Journal, vol. 27, no. 6, pp. 716-731.

[32] Lawler, E. E., (1995)."Creating High Performace Organizations: Survey of Practices and Results of Employee Involvement and TQM in Fortune 1000 Companies". Wiley.

[33] Toremen, F., Karakus, M., Yasan, T., (2009). Total Quality Management Practices in Turkish Primary Schools. Quality Assurance in Education: An International Perspective, v17 n1 p30-44.

[34] Venkatraman, S., (2007), "A framework for implementing TQM in higher education programs", Quality Assurance in Education, Vol. 15 No. 1, pp. 92-112. https://doi.org/10.1108/09684880710723052.

[35] Manatos, M., Sarrico, C.S. and Rosa, M.J. (2014), “A systematic literature review on qualitymanagement in higher education: a trend towards integration", 1st InternationalConference on Quality Engineering and Management, University of Guimaraes (Portugal) Guimaraes,September 15-16. 